\title{
Germination ECOLOGY OF CATChFLy (Silene conoidea) SEeds OF Different Colors
}

TANVEER, A. ${ }^{1 *}$
JAVAID, M.M. ${ }^{2}$

ABBAS, R.N. ${ }^{1}$

ALI, H.H. ${ }^{2}$

NAZIR, M.Q. ${ }^{1}$

BALAL, R.M. ${ }^{2}$

SHAHID, M.A. ${ }^{2}$

\section{Ecologia de Germinação de Sementes de Silene (Silene conoidea) de Diferentes Cores}

ABSTRACT - Catchfly (Silene conoidea), an annual herb, is usually recognized as an emerging weed species in Eurasia and North America. The presence of somatic seed polymorphism might aid in the adaptation of this weed in different climatic conditions. We conducted laboratory and greenhouse experiments to study the seed polymorphism and influence of various environmental factors like temperature, salt stress, osmotic stress and burial depth on the germination and emergence characteristics of catchfly. Optimum germination of seeds of all colors was recorded at a temperature of $15{ }^{\circ} \mathrm{C}$. Germination of catchfly seeds of all colors followed decreasing trend as $\mathrm{NaCl}$ concentration increased from $50 \mathrm{mM}$ to $200 \mathrm{mM}$. Seed germination was maximum (87-96\%) at $0 \mathrm{MPa}$ but gradually decreased to $40 \%$ as osmotic stress increases up to $-0.4 \mathrm{MPa}$ and completely inhibited at $0.6 \mathrm{MPa}$ of all seed colors. A slight increase (from 60 to 95\%) in the germination of seeds of black and dark brown colors was observed when seeding depth increased from 0 to $2 \mathrm{~cm}$ but decreased when seeding depth increased from 2 to $4 \mathrm{~cm}$ in seeds of all colors. There was no emergence of catchfly at seeding depth of $6 \mathrm{~cm}$ or greater. Our results concluded that catchfly seeds have the potential to germinate and emerge in various environmental conditions, but germination/emergence percentage of seeds of all colors will be different in different environmental conditions. Soil amendments including deep ploughing may aid for the successful management of this weed in cultivated areas.

Keywords: polymorphism, catchfly, germination ecology.

RESUMO - Silene (Silene conoidea), uma erva anual, é geralmente reconhecida como uma espécie emergente de plantas daninhas na Eurásia e na América do Norte. A presença de polimorfismo somático de sementes pode auxiliar na adaptação dessa planta em diferentes condições climáticas. Foram realizados experimentos em laboratório e em estufa para estudar o polimorfismo da semente e a influência de diversos fatores ambientais, como temperatura, estresse salino, estresse osmótico e profundidade de enterramento, sobre as caracteristicas de germinação e emergência de silene. A germinação ideal de sementes de todas as cores foi registrada a uma temperatura de $15^{\circ} \mathrm{C}$. A germinação de sementes de silene de todas as cores seguiu tendência decrescente à medida que a concentração de $\mathrm{NaCl}$ aumentou de $50 \mathrm{mM}$ para $200 \mathrm{mM}$. A germinação das sementes foi máxima (87-96\%) a $0 \mathrm{MPa}$, mas diminuiu gradualmente para $40 \%$ à medida que o estresse osmótico aumentou até -0,4 MPa, e foi completamente inibida em -0,6 MPa de todas as cores de sementes. Observou-se ligeiro aumento (de 60 a 95\%) na germinação de sementes de cores pretas e marrom-escuras quando a profundidade de semeadura aumentou de 0 para $2 \mathrm{~cm}$, porém houve diminuição quando a

Planta Daninha 2017; v35:e017152429

1 University of Agriculture, Faisalabad, Pakistan; ${ }^{2}$ University College of Agriculture, University of Sargodha, Pakistan. 
profundidade de semeadura aumentou de 2 para $4 \mathrm{~cm}$ em sementes de todas as cores. Não houve emergência de silene na profundidade de semeadura de $6 \mathrm{~cm}$ ou maior. Os resultados mostraram que as sementes de silene têm potencial para germinar e emergir em várias condições ambientais, mas a porcentagem de germinação/emergência de sementes de todas as cores será diferente em distintas condições ambientais. Alterações no solo, incluindo arado profundo, podem ajudar na gestão bemsucedida dessa planta em áreas cultivadas.

Palavras-chave: polimorfismo, silene, ecologia da germinação.

\section{INTRODUCTION}

Somatic seed polymorphism is probably the characteristic that is more common in weed species than in crop plants (Senseman and Lawrence, 1993). Polymorphic seeds are often produced in the same plant or in the same population by different plants (Harper, 1965). This characteristic probably aids in the survival and adaptation of weed plants in different climatic conditions. Seeds variations in color, size and weight may be signaled by the ecological conditions, internal competition for nutrients during the seed development and also by a specific genetic constitution and seed maturation. The climatic conditions under which seeds develop in the mother plant may influence their dormancy and germination (Koller, 1962; Guttermann, 1973). Williams and Harper (1965) have demonstrated that polymorphic seeds differ in their germination requirements. Bhandari (1977) has observed seven different seed coat colors and their varying imbibitions and germination behaviors in Indigofera tinctoria. The effects are attributed mainly to impermeability of the seed coat to water and oxygen, and to the mechanical strength of the seed coat which exerts sufficient restraint to the growth of the embryo (Sharma et al., 1978). Sometimes, immature seeds have germinated when incubated immediately after removal from the plant, whereas seeds that had matured in the mother plants have not germinated when incubated to the same extent (Morgan and Berrie, 1970). Such type of seeds develops dormancy during seed development in the mother plants. Knowledge of weed seed germination is critical in an agroecosystem. Germination is the process whereby seeds begin to sprout and grow. This process is affected by such factors as temperature (Widderick et al., 2004), drought (Chejara et al., 2008), salts (Chauhan et al., 2006) and burial depth (Koger et al., 2004). The present paper is concerned with the germination of catchfly (Silene conoidea) seeds. Catchfly is an annual, erect plant and a problem weed in field crops. There is a shortage of data concerning the germination ecology of catchfly. The objective of the present study was to describe some of the germination characteristics of seeds of different colors and weight collected from catchfly. The findings of this experiment will be helpful in management strategies of catchfly.

\section{MATERIALS AND METHODS}

Experiments were conducted under laboratory and greenhouse conditions during 2014. Plants of catchfly were harvested in the first week of May 2014 from plots sown for weed identification. Harvested plants were allowed to dry for a week and seeds were threshed. After threshing, seeds were air-dried for a week, placed in a paper bag and stored in the laboratory at room temperature until used in the experiments. In November 2014, seeds were separated into black, brown and dark brown categories based on their color. To determine seed fresh weight of each category, a random sample of 300 seeds was taken from each category. Fresh weight of seeds of different categories was $1.095 \mathrm{~g}$ for black, $0.844 \mathrm{~g}$ for brown and $0.937 \mathrm{~g}$ for dark brown seeds.

\section{General germination protocol}

Twenty catchfly seeds of each color were placed separately in $9 \mathrm{~cm}$ diameter Petri dishes containing filter paper Whatman No.10, moistened with $5 \mathrm{~mL}$ of distilled water or a treatment solution. Catchfly seeds were surface sterilized by soaking in $10 \%$ sodium hypochlorite $(\mathrm{NaOCl})$ for $5 \mathrm{~min}$, followed by five rinses with distilled water before the start of each germination or emergence experiment. Petri dishes were sealed with Parafilm to reduce the water loss. 
Germinated seeds with a radicle at least $2 \mathrm{~mm}$ long were counted and removed daily for three weeks. In a burial depth experiment, seedlings were considered emerged when a cotyledon was visible at the soil surface.

\section{Effect of temperature}

Germination of black, brown and dark brown seeds of catchfly was determined in a seed germinator at constant temperatures of $10,15,20$ and $25^{\circ} \mathrm{C}$ for 12 days. These temperatures were selected due to reflecting the temperature variation during the winter period in Pakistan.

\section{Effect of salt stress}

Three colored seeds of catchfly were incubated separately in a sodium chloride ( $\mathrm{NaCl}$ ) solution of $0,50,100,150$ and $200 \mathrm{mM}$ to examine the effect of salt stress on germination.

\section{Effect of osmotic stress}

Catchfly, each color of three different colors, were germinated in aqueous solution with an osmotic potential of $0,-0.2,-0.4,-0.4$, and $-0.6 \mathrm{MPa}$. Osmotic potentials were prepared by using Polyethylene glycol (PEG-6000) in distilled water. The following equation (Michel and Kaufmann, 1973) was used to calculate the amount (g) of PEG-6000 from the known water potential (MPa) required.

Water potential $=-\left(1.18 \times 10^{-2}\right) \mathrm{C}-\left(1.18 \times 10^{-4}\right) \mathrm{C}^{2}+\left(2.67 \times 10^{-4}\right) 18 \mathrm{CT}+\left(8.39 \times 10^{-7}\right) \mathrm{C}^{2} \mathrm{~T}$ where $\mathrm{C}$ is the concentration of PEG $\left(\mathrm{g} \mathrm{kg}^{-1}\right.$ distilled water) and $\mathrm{T}$ is the temperature $\left({ }^{\circ} \mathrm{C}\right)$.

\section{Effect of seeding depth}

The effect of seeding depth on seedling emergence of different seed colors of catchfly was studied in the green house. Twenty seeds of each color were placed on the soil surface or covered with soil (30\% clay, 30\% silt and 40\% sand) to depths of 2, 4, 6, 8 and $10 \mathrm{~cm}$ in $15 \mathrm{~cm}$ diameter plastic pots. Pots were left opened and watered as needed to maintain an adequate soil moisture. Seedlings were considered emerged when a cotyledon was visible at the soil surface.

\section{Statistical analysis}

A completely randomized design with four replications was used in all experiments. Nonlinear regression analysis was used to determine how $\mathrm{NaCl}$, osmotic stress or seeding depth affected germination percentage or the emergence of catchfly seeds. Germination (\%) values at different concentrations of $\mathrm{NaCl}$ and osmotic potential were fitted to a functional three-parameter logistic model using Sigma Plot 2008 (version 11.0). The model fitted was $G(\%)=G_{\max } /\left[1+\left(x / x_{50}\right)\right.$ Grate $]$, where $G$ is the total germination (\%) at concentration $x, G_{\max }$ is the maximum germination (\%), $x_{50}$ is the $\mathrm{NaCl}$ concentration or osmotic potential for $50 \%$ inhibition of the maximum germination and $G_{\text {rate }}$ indicates the slope. A three-parameter Gaussian model $\left\{E(\%)=E_{\max } \times e\left[-0.5\left(x-x_{0}\right) / E_{\text {rate }}\right]\right\}$ was fitted to three-color catchfly seedling emergence (\%) where $E$ is the total seedling emergence $(\%)$ at burial depth $x, E_{\max }$ is the maximum seedling emergence (\%), $x_{0}$ is the burial depth at which maximum seedling emergence occurred and $E_{\text {rate }}$ indicates the slope.

\section{RESULTS AND DISCUSSION}

\section{Effect of temperature}

The germination percentage of catchfly was minimum at $10^{\circ} \mathrm{C}$ for seeds of all colors. The optimum temperature was $15^{\circ} \mathrm{C}$ for seed germination as seeds of all colors showed maximum 
germination at this temperature (Figure 1). After that, germination of catchfly progressively decreased with increase in temperature. The figure shows the highest germination in dark brown seeds and more decrease in germination of black seeds with temperature variation.

\section{Effect of salt stress}

Germination of catchfly seeds followed an exponential response to increasing salt concentration, with germination decreasing as the $\mathrm{NaCl}$ concentration increased from 50 to $200 \mathrm{mM}$ (Figure 2). Black, brown and dark brown seeds of catchfly attained maximum germination percentages of 76,88 and $91 \%$, respectively, with distilled water. Black seed germination was not significantly affected at a $50 \mathrm{mM} \mathrm{NaCl}$ concentration. However, it drastically decreased at a $150 \mathrm{mM} \mathrm{NaCl}$ concentration and there was no germination at a $200 \mathrm{mM} \mathrm{NaCl}$ concentration (Figure 2). A three-parameter logistic model indicated that $50 \%$ inhibition of germination of black, brown and dark brown seeds of catchfly occurred at $\mathrm{NaCl}$ concentration of 129,135 and $134 \mathrm{mM}$, respectively (Figure 2). These data suggest that seeds of all colors of catchfly may germinate at high salinity.

\section{Effect of osmotic stress}

A three-parameter logistic model was fitted to the germination \% of three colors (black, brown, and dark brown) of catchfly seeds at different osmotic potentials (Figure 3). In dark seeds, maximum germination was $87 \%$ with distilled water and it significantly decreased with increasing osmotic stress. Germination of dark seeds of catchfly was completely inhibited at the osmotic potential of $-0.6 \mathrm{MPa}$. The fitted model estimated that 50\% inhibition of the maximum germination of catchfly was recorded at the osmotic potential of $-0.33 \mathrm{MPa}$. Germination of brown seeds was $92 \%$ at $0 \mathrm{MPa}$ osmotic potential and drastically decreased with increasing osmotic potential. Germination was completely inhibited at the osmotic potential of $-0.6 \mathrm{MPa}$. A threeparameter logistic model estimated that the osmotic potential required for $50 \%$ inhibition of the maximum germination of brown seeds of catchfly was $-0.35 \mathrm{MPa}$ (Figure 3). Germination of the dark brown seed of catchfly decreased from $96 \%$ to $40 \%$ when osmotic stress increased from 0 to $-0.4 \mathrm{MPa}$ and completely inhibited at $-0.6 \mathrm{MPa}$. A three-parameter

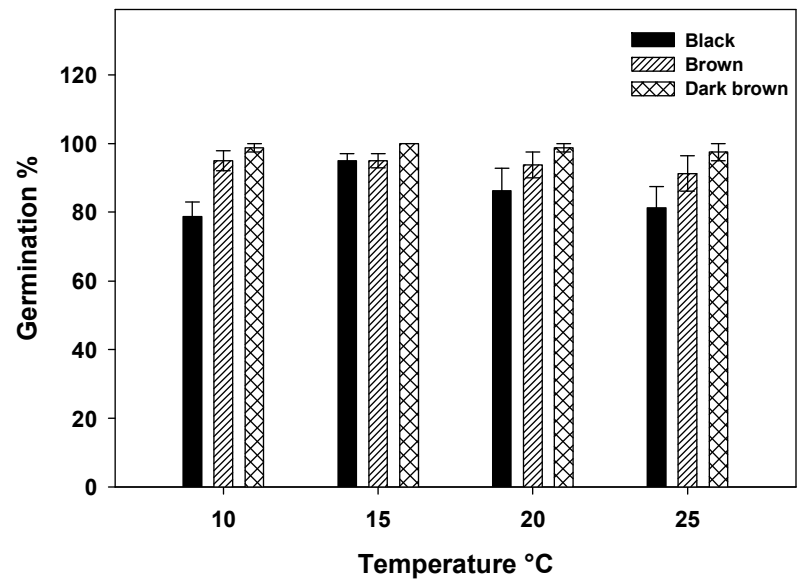

Figure 1 - Effect of temperature on the germination of black, brown and dark brown seeds of catchfly.

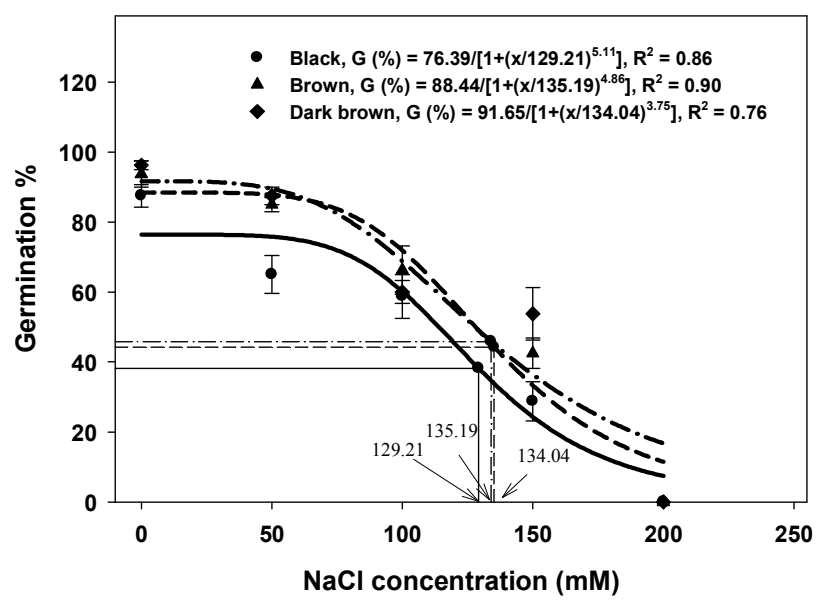

The line represents the functional three-parameter logistic model $\left\{\mathrm{G}(\%)=\mathrm{G}_{\max } /\left[1+\left(\mathrm{x} / \mathrm{x}^{50}\right) \mathrm{G}_{\text {rate }}\right]\right\}$ fitted to the data.

Figure 2 - Effect of sodium chloride $(\mathrm{NaCl})$ on the germination of black, brown and dark brown seeds of catchfly.

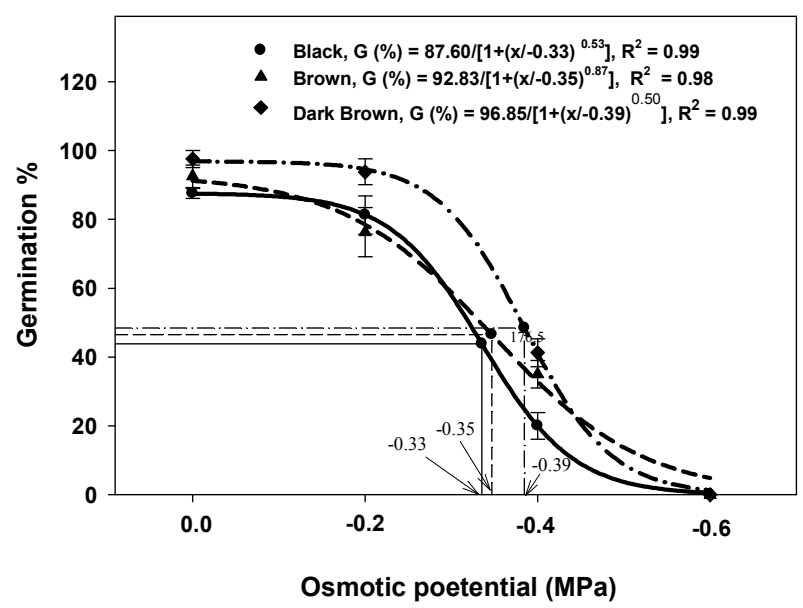

The line represents the functional three-parameter logistic model $\left\{\mathrm{G}(\%)=\mathrm{G}_{\max } /\left[1+\left(\mathrm{x} / \mathrm{x}^{50}\right) \mathrm{G}_{\text {rate }}\right]\right\}$ fitted to the data.

Figure 3 - Effect of osmotic potential on the germination of black, brown and dark brown seeds of catchfly. 
logistic model showed that the osmotic potential for $50 \%$ inhibition of the maximum germination of catchfly was $-0.39 \mathrm{MPa}$ (Figure 3 ).

\section{Effect of seeding depth}

A three-parameter Gaussian model was fitted to the seedling emergence of dark, brown and dark brown seeds of catchfly (Figure 4). The emergence of black and dark brown seeds of catchfly was stimulated from $80 \%$ and $60 \%$, respectively to $96 \%$ when seeding depth was increased from 0 to $2 \mathrm{~cm}$ but declined when seeding depth was further increased to $4 \mathrm{~cm}$. However, there was no emergence of these seeds recorded at a seeding depth of $6 \mathrm{~cm}$ or greater. A three-parameter Gaussian model was fitted to the emergence value of dark seeds of catchfly when placed and estimated that the maximum emergence $(96 \%)$ was recorded at a seeding depth of $1.07 \mathrm{~cm}$. The emergence of brown seeds of catchfly was minimum when compared to those of dark or dark brown seeds. A three-parameter Gaussian model showed that maximum emergence (42\%) of brown seeds was at $1.53 \mathrm{~cm}$ seeding depth.

Survival of plants may be dependent on various factors such as germination regulating mechanism, defensive mechanisms or dormancy. Seeds of catchfly may utilize the germination regulating mechanism and strategies for survival. Various biological and environmental factors and their interaction may serve as a signal by which germination is triggered in order to take advantage of environmental conditions that maximize the probability for successful establishment. In the absence of such signal, most of the seed population remains dormant. Morphological variations among polymorphic seeds of catchfly are considerably correlated with the germination ability of seeds, with black seeds being less dormant than brown and dark brown seeds. Black seeds showed the highest rate and germination percentage while brown seeds showed the lowest rate and percentage of germination. Brown seeds were more susceptible to change in temperature being more dormant at low and high temperatures as compared to dark brown and black seeds which are more tolerant to variations in temperature for germination. It might be because low temperature probably maintains dormancy in seeds during the winter and early spring. Similarly, Khan and Ungar (1984a) have recorded a high germination of A. triangularis at a moderate temperature as compared to low and alternating temperature. The maximum rate of germination in all polymorphic seeds of catchfly is recorded at 20 and $25{ }^{\circ} \mathrm{C}$ as compared to higher and lower temperatures. This shows that a moderately high temperature appeared to be playing a significant role in promoting germination. This increase in germination rate could be due to an enhanced metabolic activity (Koller and Hadas, 1982), increased water uptake by seeds (Uchiyama, 1981; Koller and Hadas, 1982) and changes in membrane permeability (Taylorson and Hendricks, 1977). However, the exact nature of these mechanisms is not properly understood (Ungar, 1982).

Polymorphic seeds of catchfly showed a differential response towards salinity. The germination percentage of brown seeds was significantly inhibited by exposure to salt stress. Dark brown and black seeds showed more tolerance to salt stress. However, an increasing salinity concentration seems to induce dormancy. Seeds of many species remain dormant at a low water potential. These seeds do not lose viability and are going to germinate when subjected to a distilled water treatment (Ungar, 1982; Khan and Urgar 1984b). This could be of ecological significance since the germination of seeds in early spring, when high soil moisture level reduces salinity stress, probably assumed that some plants would survive until the growing season later in the summer (Ungar, 1982).

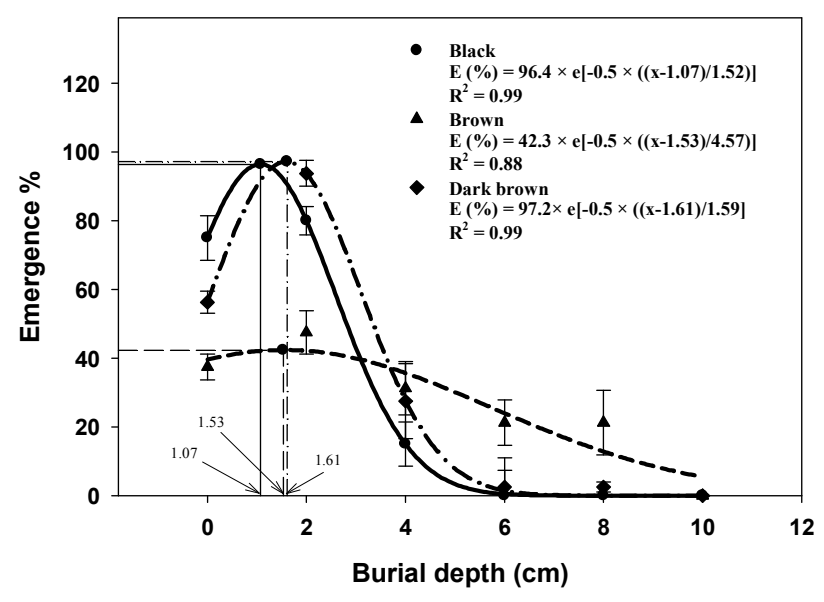

The line represents the functional three-parameter Gaussian model $\left\{E(\%)=E_{\max } \times e\left[-0.5\left(x-x_{0}\right) / E_{\text {rate }}\right]\right\}$ fitted to the data.

Figure 4 - Effect of burial depth on the emergence of black, brown and dark brown seeds of catchfly. 
The absence of osmotic stress improved the rate and percentage of germination, particularly of (large) black seeds. Germination was not significantly affected even at the lower level of osmotic stress but with an increase in osmotic stress, rate and percentage of germination was declined to no germination at the highest level of osmotic stress. This might be due to the seeds ability to uptake water. Uchiyama (1981) has related seed germination to the rate of water absorption. He believed that irrespective of temperature, when water contents of seeds of $A$. nummularia reached $70 \%$, seeds would germinate. Springfield (1970) has revealed that the imbibition in A. canescens depends on whether the seeds are winged or dewinged. The rate of imbibition of dewinged seeds was faster than winged seeds. Nobs and Hagar (1974) have shown that during the first 5 hours, the large brown seeds of $A$. hortensis had a very rapid rate of water imbibition. The small black seeds showed a considerably slower rate of water uptake. Germination of horse-weed decreased from 25 to $2 \%$ as osmotic potential decreased from 0 to $-0.8 \mathrm{MPa}$ (Nandula et al., 2006). Germination of catchfly polymorphic seeds was gradually decreased with increase in osmotic stress level, with a pronounced effect on the brown seed, which may be due to its genetic potential. Germination over a broad range of osmotic potential indicated that catchfly seeds could pose a weed threat under both adequate and moisture stress soil conditions. This also implies that (large) black seeds are going to show a nearly complete germination in soil seed bank while (small) brown seeds are going to provide a longer term seed bank. This behavior is most likely related to the differences in physiological responses to polymorphic seeds and fluctuations in soil conditions during the growing season (Wertis, 1982) which limits the periods when seeds can germinate. Rate, as well as percentage emergence of polymorphic seeds of catchfly, dramatically decreased with increasing plant depth. Most of the emergence of all types of seeds occurred from 0-4 cm. Bhowmik and Bekech (1993) have reported 80\% emergence of horseweed seeds in the top $2 \mathrm{~cm}$ soil, but no emergence was found at a depth greater than $6 \mathrm{~cm}$. Brown (small) catchfly seeds showed the lowest emergence at a depth greater than $4 \mathrm{~cm}$, which might be due to the difficulty in the emergence of weak seedlings due to fewer food reserves. The emergence of weeds is affected by the amount of food reserves in seeds and the depth of burial in soil (Nandula et al., 2006). Decreased emergence due to increase in planting depth has been reported in several weed species such as hairy beggar ticks (Reddy and Singh, 1992) and horse purslane (Balyan and Bhan, 1986). Under field conditions, no-tillage or shallow or minimum tillage practices may encourage germination and emergence of catchfly seeds.

Our study has clearly demonstrated an ecological significance of the polymorphic seeds in catchfly. The various seed sizes and colors have different tolerance limits to temperature, salinity, osmotic stress and planting depth. All of the (large) black seeds may germinate early in the growing season. Brown (small) seeds may germinate throughout the season and are more dormant. These results suggest that catchfly has the ability to germinate under a broad range of ecological conditions. Prevailing conditions could determine the extent of germination, subsequent emergence and overall problem of catchfly.

\section{REFERENCE}

Balyan R.S., Bhan V.M. Germination of horse pursulane (Trianthema portulacastrum) in relation to temperature, storage condition and seeding depth. Weed Sci. 1986;34:513-5.

Bhandari D.C. Studies on arid zone legumes with special reference to Indigofera species-their ecology, nitrogen metaholism and role in cropecosystem [thesis] Jodhpur: University of Jodhpur, 1977.

Bhowmik P.C., Bekech M.M. Horseweed (Conyza canadensis) seed production, emergence, and distribution in no-tillage and conventional-tillage corn (Zea mays)." Agron Trends Agric Sci. 1993;1:67-7.

Chauhan B.S. et al. African mustard (Brassica tournefortii) germination in southern Australia. Weed Sci. 2006;54:891-89.

Chejara V.K. et al. Factors affecting germination of coolatai grass (Hyparrhnia hirta). Weed Sci. 2008;56:543-8.

Guttermann Y. Differences in the progeny due to day length and hormone treatment of the mother plant. W-Heydeckered. Seed ecology. London: Pennsylvania State University Press, 1973. p.59-80.

Harper J.L. Establishment, aggression and cohabitation in weedy species. In: Baker I.M., Stebbins G.L., editores. The genetics of colonization species. New York: Academic Press, 1965. p.243-68. 
Khan M.A., Ungar I.A. Seed polymorphism and germination responses to salinity stress in Atriplex triangularis willd. Bot Gazette. 1984b;155:487-94.

Khan M.A., Ungar I.A. The effect of salinity and temperature on germination of polymorphic seeds and growth of Atriplex triangularis Willd. Am J Bot. 1984a;71:481-9.

Koger C.H. et al. Factors affecting seed germination seedling emergence and survival of Texas weed (Caperonia palustris). Weed Sci. 2004;52:989-95.

Koller D., Hadas A. Water relation in the germination of seeds. In: Lange O.L. et al., editores. Encyclopedia of plant physiology; Physiological plant ecology. Berlin: Springer, 1982. v.2. p.402-31.

Koller D.O.V. Preconditioning of germination in lettuce at time of fruit ripening. Am J Bot. 1962;9:841-9.

Michel B.E., Kaufmann M.R. The osmotic potential of polyethylene glycol 6000. Plant Physiol. 1973;51:914-6.

Morgan S.F., Berrie A.M.M. Development of dormancy during seed maturation in avena ludoviciana winter wild oat Development of dormancy during the seed maturation in Avena Iudoviciana winter wild oat. Nature. 1970;228:1225.

Nandula V.K. et al. Factors affecting germination of horse weed (Conyza Canadensis). Weed Sci. 2006;54:898-902.

Nobs M.A., Hagar W.A. Analysis of germination and flowering rates of dimorphic seeds of Atriplex hortensis. Ann Rep Dep Plant Biol Carnegie Inst. 1974;7:859-64.

Reddy K.N., Singh M. Germination and emergence of hairy beggar ticks (Bidens pilosa). Weed Sci. 1992;40:195-99.

Senseman S.A., Lawrence R.O. Flowering patterns, seed production, and somatic polymorphism of three weed species. Weed Sci. 1993;41:418-25.

Sharma N.K. et al. Seed perpetuation in Rhynchosia capitata DC. Biologia Plant. 1978;20:225-8.

Springfield H.W. Germination characteristics of Atriplex canescens seed. Inter Grass Land Congr Proc. 1970;11:586-9.

Taylorson R.B., Hendricks S.B. Dormancy in seeds. Ann Rev Plant Physiol. 1977;28:331-54.

Uchiyama Y. Studies on the germination of salt bushes. I. the relationship between temperature and germination of Atriplex nummularia (Lindl). Japanese J Trop Agric. 1981;25:62-7.

Ungar I.A. Germination ecology of halophytes. In: Sen D.N., Rajpurohit K.S., editores. Contribution to ecological of halophytes. The Hague: 1982. v.2. p.143-54.

Wertis B.A. Aspects of the population biology of halophytes Atriplex triangularis [dissertation] Athens: Ohio University, 1982.

Widderick M. et al. Better management of common sowthistle (Sonchus oleraceus) based on weeds ecology. In: Proceedings of the $14^{\text {th }}$ Australian weeds conference. Wagga: New South Wales, 2004. p.535-7.

Williams J.T., Harper J.L. Seed polymorphism and germination. I. The influence of nitrates and low temperatures on the germination of Chenopodium album. Weed Res. 1965;5:141-50. 